\title{
Fragment ,zaginionej kroniki dominikańskiej” w zbiorach Rosyjskiej Biblioteki Narodowej w Petersburgu
}

\author{
Pamięci Jana Andrzeja Spieża OP
}

(1941-2020)

Zarys treści: Przedmiotem artykułu jest prezentacja odnalezionego w zbiorach Rosyjskiej Biblioteki Narodowej w Petersburgu nowego źródła do najstarszych dziejów polskich dominikanów. Powstało ono zapewne w pierwszej połowie XIII w. Zawiera wiele nowych informacji, m.in. ostatecznie przecina spekulacje na temat czasu przybycia św. Jacka do Krakowa, który niewątpliwie został posłany do Polski w 1222 r. Odnaleziony tekst jest najprawdopodobniej fragmentem tzw. zaginionej kroniki dominikańskiej.

\begin{abstract}
The article presents a new source found in the National Library of Russia in Saint Petersburg. This is the oldest source for the history of the Polish Dominicans. It was probably produced in the first half of the thirteenth century. It contains some new information, among others it finally puts an end to speculation about the time of St Hyacinth arrival in Cracow, who was undoubtedly sent to Poland in 1222. The found text is most probably a fragment of the so-called 'lost Dominican chronicle'.
\end{abstract}

Słowa kluczowe: dominikanie, kronika dominikańska, Liber beneficiorum dioecesis Cracoviensis, św. Jacek Odrowąż, Jan Długosz

Keywords: Medieval Dominicans, Dominican chronicle, Liber beneficiorum dioecesis Cracoviensis, St Hyacinth of Poland, Jan Długosz

\section{Wstęp}

Nie będzie przesadą stwierdzenie, że narracja założycielska ${ }^{1}$ Polskiej Prowincji Zakonu Kaznodziejskiego ma faktycznie jednego autora. Jest nim krakowski dominikanin - lektor Stanisław². Około lat 60. XIV w. stworzył on opowieść o życiu i cudach cieszącego się opinią świętości brata Jacka Odrowąża3.

\footnotetext{
${ }^{1}$ Wiele przedstawionych w niniejszym studium ustaleń zawdzięczam współpracy i dyskusjom z Panem Profesorem Markiem D. Kowalskim, któremu pragnę w tym miejscu serdecznie podziękować. Narracja założycielska (ang. Founding narrative, niem. Gründungsnarrative) jest pierwowzorem literackim wyznaczającym zarówno wzorzec opisu dla późniejszego pisarstwa, jak i kształtującym powszechne imaginarium.

2 M. Zdanek, Stanistaw (zm. po 1371 a przed 1385-1392), w: PSB, t. 42, Kraków 2003, s. 7-9.

${ }^{3}$ De vita et miraculis sancti Iacchonis (Hyacinthi) Ordinis Fratrum Praedicatorum auctore Stanislao lectore Cracoviensi eiusdem Ordinis, wyd. L. Ćwikliński, w: MPH, t. 4, Lwów 1884, s. 841-894. Najnowszy polski przekład z aparatem źródłowym i filologicznym zob. Lektor Stanisław z Krakowa, Życie i cuda świętego Jacka z Zakonu Braci Kaznodziejów, tłum.
} 
Jacek - według Stanisława - miał w 1217 r. zostać posłany do Polski przez założyciela Zakonu św. Dominika z Caleruegi i być głównym twórcą prowincji oraz organizatorem sieci klasztornej. To właśnie z inicjatywy Jacka miały powstać klasztory we Wrocławiu i Pradze. On też osobiście miał uczestniczyć w powstawaniu domów we Fryzaku, Kijowie i Gdańsku. Jacek został przedstawiony przez lektora Stanisława jako alter Christus, Dominicus, Paulus, Stanislaus, Adalbertus, a nawet alter Boleslaus (Chrobry) ${ }^{4}$.

Dzieło Stanisława mogło usatysfakcjonować czcicieli brata Jacka i amatorów literatury hagiograficznej, ale stanowiło i nadal stanowi niemałe wyzwanie dla historyków. Już w XV w. Jan Długosz, pisząc Roczniki i Liber beneficiorum dioecesis Cracoviensis [dalej: LB], stanął przed trudnym zadaniem: w jaki sposób uzgodnić opowieść lektora Stanisława z innymi wiarygodnymi źródłami? I nie chodziło wyłącznie o poważne rozbieżności w chronologii - dodajmy, że niemal każda data podana przez hagiografa jest błędna5 ${ }^{5}$ Tym zaś, co mogło rzeczywiście zaskoczyć Długosza w trakcie lektury dostępnych mu źródeł, to inna od Stanisławowej historia początków polskich dominikanów, w tym również - co trzeba podkreślić - biografia brata Jacka. Choć Długosz nie odrzucił przekazu lektora Stanisława, to zupełnie inaczej rozłożył akcenty i wprowadził wiele nowych informacji. Napisał on nowe „opowiadanie założycielskie", a brat Jacek otrzymał w nim nieco inną rolę.

Nie ulega wątpliwości, że Długosz, przedstawiając (zwłaszcza w LB) relację odmienną od Żywota $s ́$ w. Jacka, musiał dysponować wiarygodnym materiałem źródłowym. W ten sposób wchodzimy w krąg dyskusji na temat „nieznanych źródel”, a zwłaszcza „zaginionej kroniki dominikańskiej”. Historycy jak zobaczymy w pierwszej części niniejszego studium - od 70 lat starają się poznać i zrekonstruować to zaginione źródło. I gdy wydawało się już, że na zawsze pozostaniemy w sferze hipotez, odnalezione zostało średniowieczne źródło, które otwiera zupełnie nową perspektywę w badaniach nad „zaginioną kroniką dominikańską" i początkami dominikanów w Polsce.

\section{70 lat badań nad „zaginioną kroniką dominikańską”}

W 1951 r. Raymond-Joseph Loenertz OP opublikował studium na temat średniowiecznych prowincjałów Polskiej Prowincji Zakonu Kaznodziejskiego ${ }^{6}$. Punktem wyjścia i podstawą źródłową analiz uczynił liste prowincjałów dominikańskich z LB Jana Długosza ${ }^{7}$. Na ten fragment dzieła XV-wiecznego historiografa zwracali uwagę choćby Jan Fijałek ${ }^{8}$ i Jacek Woroniecki ${ }^{9}$, ale dopiero R.-J. Loenertz podjął wysiłek gruntownego opracowania całego przekazu na podstawie przysłanych mu z Krakowa fotografii rękopisu. Historyk ten przygotował nową edycję listy prowincjałów oraz opatrzył ją komentarzem, który zawierał wiele uściśleń, korekt i obserwacji. Zauważył m.in., że Długosz, redagując tę

T. Gałuszka, w: Święty Jacek Odrową̇̇. Studia i źródła. Skarby dominikańskie, red. M. Zdanek, Studia i Źródła Dominikańskiego Instytutu Historycznego w Krakowie, t. 2, Kraków 2007, s. 101-155. Przegląd najnowszych badań nad Żywotem św. Jacka przedstawił M. Kulpa, Wokół czternastowiecznego „Żywota św. Jacka”- kilka zagadnień źródłoznawczych, „Nasza Przeszłość", 132, 2019, s. 5-51.

${ }^{4}$ M. Zdanek, Figury $i$ wątki biblijne w „Przedmowie” do „Żywota Świętego Jacka”, w: Święty Jacek i dziedzictwo dominikańskie, red. E. Mateja, A. Pobóg-Lenartowicz, M. Rowińska-Szczepaniak, Opole 2008, s. 163-175; tenże, Figury biblijne w literackim wizerunku świętego Jacka w świetle jego najstarszej hagiografii, „Przegląd Tomistyczny”, 14, 2008, s. 29-61; T. Gałuszka, „In finibus Poloniae”. Patroni i bohaterowie Polski w czternastowiecznym „Żywocie św. Jacka” autorstwa lektora Stanisława OP, w: Dominikanie o Polsce i Polakach od XIII do XX wieku, red. T. Gałuszka, K. Matyja, Studia i Źródła Dominikańskiego Instytutu Historycznego w Krakowie, t. 21, Kraków 2020, s. 19-41.

5 T. Gałuszka, M. Zdanek, , Krakowskie” bulle rekomendacyjne Grzegorza IX a początki dominikanów polskich, St. Źródł., 44, 2006, s. 49-65; J.A. Spież, Kilka uwag o chronologii życia św. Jacka, w: Święty Jacek i dziedzictwo dominikańskie, s. 17-39.

${ }^{6}$ R.-J. Loenertz, Un ancienne chronique des provinciaux dominicains de Pologne, „Archivum Fratrum Praedicatorum”, 21, 1951, s. 5-50.

7 Joannis Dlugosz senioris canonici Cracoviensis Liber beneficiorum dioecesis Cracoviensis, t. 3, wyd. A. Przezdziecki, Cracoviae 1864 [dalej: LB], s. 450-453.

${ }^{8}$ Zbiór formuł zakonu dominikańskiego prowincji polskiej z lat 1338-1411, przedł. do dr. J. Woroniecki, wstęp i wyd. J. Fijałek, Kraków 1938, s. 240.

9 J. Woroniecki, Święty Jacek Odrowąż i sprowadzenie Zakonu Kaznodziejskiego do Polski, wyd. 2, Kraków-Katowice 2007, s. 281-285. 
listę, skorzystał przynajmniej z dwóch źródeł o proweniencji dominikańskiej - nazwał je la chronique A i la chronique $B$. Według niego pierwsza z kronik miałaby być jednym dziełem (une auvre), które miałoby być rozpoczęte jeszcze w XIII w. i konsekwentnie uzupełniane przez kolejnych autorów aż do końca XIV w.; kronikę otwierała informacja o pierwszym prowincjale Gerardzie (nota nr 1: prowincjalat w latach 1225-1233), a zamykała wzmianka o wyborze Piotra Wasserrabe (nota nr 31: prowincjalat w latach 1392-1396). Z kolei kronika B miała dotyczyć uzupełnień sygnalizowanych przez samego Długosza jako alia annalia. Zdaniem R.-J. Loenertza „kronika B była dokumentem (une document) z XIII w."; zaproponował on również dokładniejszą datację powstania tego źródła - na lata 60 . XIII w. ${ }^{10}$

Kilka lat później ustalenia R.-J. Loenertza poddał krytyce Jerzy Kłoczowski, zgłaszając wiele zastrzeżeń do hipotezy istnienia jednej „kroniki A” ${ }^{\prime 1}$. Po pierwsze, stanowczo odrzucił on nazywanie tego źródła w ogóle „kroniką”, uznając je po prostu za listę prowincjałów ${ }^{12}$. Po drugie, podważył tezę, że źródło to miało kształt jednego dzieła ${ }^{13}$. Zaproponował zaś, aby „kronikę A” nazywać listą lub katalogiem prowincjałów, która była złożona z kilku części powstałych na przestrzeni prawie 200 lat. W przypadku zaś „kroniki B” uznał, że mamy do czynienia nie tyle z kroniką, ile z jakimś rocznikiem dominikańskim. Ponadto wysunął hipotezę, że informacje Długosza m.in. o zorganizowaniu przez pierwszego prowincjała Gerarda z Wrocławia kapituły i tzw. rozesłaniu braci mogą pochodzić również z tego XIII-wiecznego rocznika. Długosz więc - według przypuszczeń J. Kłoczowskiego - miałby uzupełnić katalog (kronika A) wypisami z rocznika (kronika B).

Badania R.-J. Loenertza i J. Kłoczowskiego zostały wykorzystane przez Gerarda Labudę, który w 1959 r. wprowadził hipotezę o istnieniu ,zaginionej kroniki dominikańskiej” z XIII w. ${ }^{14}$ W 2002 r., bodaj w ostatnim studium dotyczącym tego zagadnienia, poznański historyk zebrał swoje dotychczasowe ustalenia: ,zaginiona kronika" miała formę jednego zwartego dzieła powstałego po 1260 r., obejmowała lata 1202-1265, stanowiła kontynuację kroniki Wincentego Kadłubka, jej autorem był dominikanin Wincenty (z Kielczy/ Kielc?), a miejscem przechowywania zapewne klasztor dominikanów w Raciborzu ${ }^{15}$. Kluczowym zaś dowodem na istnienie takiego dzieła miał być - zdaniem G. Labudy - katalog prowincjałów z Długoszowego LB, a zwłaszcza znajdujące się na jego marginesach wypisy z alia annalia (kronika B/rocznik).

Hipoteza G. Labudy stała się przedmiotem ożywionej i wciąż nierozstrzygniętej debaty ${ }^{16}$. Maciej Zdanek stwierdził, że nie można w przekonujący sposób uzasadnić hipotezy o istnieniu jednego zaginionego źródła, które miałoby wyjść spod pióra jednego dominikańskiego kronikarza. Tam, gdzie G. Labuda widział „zaginioną kronikę”, można bez większych problemów wskazać wiele różnej proweniencji źródeł, z których skorzystał Długosz, a które nie zostały uwzględnione przez poznańskiego historyka. „Nadwyżki faktograficzne” Długosza były efektem jego kwerendy dokumentowej, zbierania lokalnych tradycji, racjonalnej analizy i amplifikacji ${ }^{17}$. W opinii M. Zdanka „zaginiona kronika dominikańska" jest raczej konceptem G. Labudy i tego rodzaju zabytek, zawierający informacje z zakresu XIII-wiecznej polityki państwowej i kościelnej, w takim kształcie, w jakim uczony próbował je zrekonstruować, najprawdopodobniej nigdy nie istniał. W konkluzji artykułu stwierdził: „Moim zdaniem odrębne zapiski powstały w konwencie krakowskim. Był to pierwszy zachowany do dziś Katalog prowincjałów polskich”18. Zaproponował, by tego zaginionego źródła nie nazywać „kroniką”, ale „roczni-

${ }^{10}$ R.-J. Loenertz, Un ancienne chronique, s. 11-13 (tłum. T.G.).

11 J. Kłoczowski, Przyczynek do krytyki „Liber Beneficiorum” Dlugosza, St. Źródł., 2, 1958, s. 155-161.

12 Tamże, s. 157.

13 Tamże.

${ }^{14}$ G. Labuda, Wojna z Tatarami w roku 1241, Przegl. Hist., 50, 1959, z. 2, s. 196; tenże, Zaginiona kronika z pierwszej połowy XIII wieku w „Rocznikach Królestwa Polskiego” Jana Dlugosza. Próba rekonstrukcji, Poznań 1983.

15 Tenże, Nowe spojrzenie na źródła dotyczące dziejów dominikanów w Polsce XIII-XIV wieku. Lektor Stanisław i jego „Żywot św. Jacka”, w: Dominikanie w środkowej Europie w XIII-XV wieku. Aktywność duszpasterska i kultura intelektualna, red. J. Kłoczowski, J.A. Spież, Poznań 2002, s. 45-64.

${ }^{16}$ M. Zdanek, „Zaginiona kronika dominikańska” z XIII wieku. Próba nowego spojrzenia, w: Fontes et historia. Prace ofiarowane Antoniemu Gąsiorowskiemu, Poznań 2007, s. 251-252.

17 Tamże, s. 278.

18 Tamże, s. 281. 
kiem dominikanów krakowskich". Zabytek miałby mieć formę rocznika i być prowadzonym w siedzibie prowincjała, czyli w klasztorze krakowskim. „Tak jak pierwsze kroniki zakonne, mógł on odnotowywać zwłaszcza fakt odbywania się kapituł prowincjalnych i generalnych (z którymi wiązały się ważne również dla prowincji polskiej wydarzenia), daty rządów prowincjałów i inne szczególne istotne zdarzenia" ${ }^{19}$. Według M. Zdanka jednym z możliwych autorów tego rocznika - lub co najmniej informatorów - był Marcin z Sandomierza, prowincjał w latach 1244-124720.

Do wspomnianego artykułu M. Zdanka odniósł się zasłużony dominikański historyk Jan Andrzej Spież OP, który w 2012 r. ogłosił studium poświęcone katalogowi prowincjałów z LB, a szczególnie pierwszej nocie zawierającej informacje o prowincjale Gerardzie i tzw. rozesłaniu krakowskim w 1225 r. ${ }^{21}$ J.A. Spież, podobnie jak M. Zdanek, sięgnął do rękopisu dzieła Długosza i potwierdził, że katalog z pewnością został zapisany przez dwóch pisarzy. W przypadku pierwszej noty pierwszy pisarz podał: „Frater Gerardus nacione Wratislauiensis, studens Parisiensis, primus provincialis Polonie, per Jordanum magistrum generalem Ordinis Praedicatorum praeficitur anno Domini millesimo ducentesimo vicesimo quinto" i pozostawił puste miejsce, w którym następnie drugi pisarz drobniejszym pismem odnotował: ,absque omni fratrum electione. Hic Cracouiam ueniens, primum ibi celebravit capitulum, de quo misit fratres recipere domos: Vratislauiensem, Pragensem, Camnenensem, Sandomiriensem", a na lewym marginesie ten sam pisarz dodał jeszcze „Gdanenesem”22. Według J.A. Spieża, „Długosz korzystał tutaj z jakiegoś źródła, które przedstawiało tradycję o początkach prowincji polskiej dominikanów w inny sposób niż ten, który w czasach kronikarza był powszechnie przyjęty. To nieznane źródło, niezgodne z coraz silniejszą Jackową tradycją początków prowincji, zapewne z tego powodu zostało zapomniane i zaginęło. Szukając jego pochodzenia, trzeba cofnąć się do czasów wcześniejszych, najpóźniej do 60. lat XIII stulecia, zanim jeszcze dominikanie krakowscy zaczęli intensywnie propagować kult św. Jacka. [...] Autora tego nieznanego źródła trzeba szukać w gronie pierwszego lub drugiego pokolenia braci, tych, którzy należeli do ówczesnej elity prowincji i dobrze znali problemy, jakimi żył zakon. Na pierwszy plan wysuwa się, tu [...] brat Wincenty z Zakonu Braci Kaznodziejów"23.

Refleksje przedstawione przez J.A. Spieża były ostatnim tak ważnym głosem w debacie zainicjowanej przez R.-J. Loenertza. Trzeba docenić wysiłki wszystkich historyków, którzy niestrudzenie próbowali odkryć i poznać to „zaginione źródło”, do którego ponad 500 lat temu miał dostęp Jan Długosz. Szczęśliwie w trakcie analizy jednego z kodeksów przechowywanych w zbiorach Rosyjskiej Biblioteki Narodowej w Petersburgu zdobyliśmy wreszcie dowód na istnienie „,zaginionej kroniki dominikańskiej”, a mianowicie fragment ex cronicis fratrum. I powiedzmy od razu, że odnaleziony fragment jest zbieżny z tekstem, który Długosz umieścił w pierwszej nocie katalogu prowincjałów i któremu J.A. Spież poświecił w 2012 r. osobne studium.

\section{Prezentacja rękopisu}

W 2018 r. w ramach projektu pt. Stownik Biograficzny Polskich Mendykantów w Średniowieczu. Tom 1: Dominikanie ${ }^{24}$, prowadzonego pod auspicjami Dominikańskiego Instytutu Historycznego w Krakowie, Marek Miławicki OP i Michał Skoczyński przeprowadzili kwerendę w zbiorach Rosyjskiej Biblioteki Narodowej w Petersburgu. Wśród analizowanych jednostek bibliotecznych polscy badacze zwrócili uwagę na średniowieczny rękopis z zespołu nr 955 o sygnaturze Lat. I F $212^{25}$.

\footnotetext{
19 Tamże, s. 282.

20 Tamże; zob. też J. Kłoczowski, Marcin z Sandomierza, w: PSB, t. 19, Wrocław 1974, s. 570-571.

21 J.A. Spież, Początki dominikanów w Polsce wedlug „Liber beneficiorum” Jana Dlugosza na tle najstarszych żywotów św. Dominika, Rocz. Hist., 78, 2012, s. 51-82.

${ }^{22}$ LB, s. 450; edycja za: J.A. Spież, Poczatki dominikanów, s. 55.

23 J.A. Spież, Poczatki dominikanów, s. 78.

${ }^{24}$ Baza danych polskich dominikanów z lat 1222-1500 jest dostępna stronie: <www.sop.dominikanie.pl> [dostęp: 28.06.2021].

${ }_{25}$ Каталог собрания латинских рукописей. Теология, сост. М.Г. Логутова, ред. О.Н. Блескина, С.А. Давыдова, Санкт-Петербург 2015, nr 71.
} 
Rękopis ten już w 1991 r. został opisany przez Elżbietę Balcerzową ${ }^{26}$, ale nigdy nie znalazł się w centrum zainteresowania polskich historyków. M. Skoczyński przeprowadził wstępne rozpoznanie rękopisu, podjął się sprowadzenia jego podobizn oraz przygotowuje osobną publikację prezentującą ten zabytek.

W tym miejscu zwrócę uwagę na kilka najważniejszych informacji na temat tego kodeksu. Jest to rękopis papierowy o wymiarach 31 x $22,5 \mathrm{~cm}$, zawiera 128 kart papierowych zapisanych przez różnych pisarzy, drewniana oprawa pokryta jest do połowy skórą z roślinnymi tłoczeniami oraz z metalową klamrą, a na oprawie znajduje się naklejona XV-wieczna nota z tytułem tomu: „Registrum [...] Michaelis Rereris lectoris et supprioris [...] ab anno Domini 1436 [...]", widać dopisek wykonany inną ręką (XVII w.): ,ad annum 1521”. Na pergaminowej wyklejce przedniej oprawy znajduje się nota sporządzona 17 IV 1436 przez lektora i subprzeora konwentu dominikanów wrocławskich, brata Michała Rerera (zm. 1467) ${ }^{27}$. Poza znakami bibliotecznymi Rosyjskiej Biblioteki Narodowej brak jakichkolwiek innych znaków proweniencyjnych, np. sygnatur, pieczęci klasztornych czy exlibrisów. W kodeksie znajdują się różnego rodzaju teksty: listy braci z Wrocławia, rachunki klasztoru, inwentarze zakrystii i biblioteki, wykaz dokumentów papieskich, odpisy dokumentów z XIII-XV w., wykazy scriptores ordinis praedicatorum, formuly dokumentów, fragmenty modlitw i pomocy kaznodziejskich, drobne notatki o charakterze probationes calami; w kodeksie znajdują się również odpisy dokumentów klasztoru dominikanek wrocławskich i dominikanów z Krosna Odrzańskiego. Teksty te w przeważającej części zostały zapisane przez wielu pisarzy w XV w. (I-II; k. 1-58v, 79v-128v); najprawdopodobniej ostatnie XV-wieczne wpisy powstały w latach 90 . tegoż wieku (k. 51v). Znajdujemy również teksty wykonane kursywą XVI-wieczną: drobne uzupełniania z lat 1519-1524 (k. 51v-52r), dokumenty klasztorne z 1519 r. i rozliczenia kwestarskie z lat 1512-1521 (k. 64-78v).

$\mathrm{W}$ trakcie analizy rękopisu zwróciłem uwagę na grupę tekstów zapisanych na k. 56v. Zostały one sporządzone przez jednego anonimowego pisarza, staranną kursywą gotycką, zredagowane w dwóch kolumnach. Autor umieścił na końcu wpisu datę 1481, którą należy łączyć z momentem wykonania całego wpisu na tej karcie.

W tekście można wyróżnić pięć części:

1) Odpis dokumentu fundacyjnego klasztoru dominikanów we Wrocławiu, wystawionego 1 V 1226 przez biskupa wrocławskiego Wawrzyńca ${ }^{28}$.

2) Odpis niedatowanego dokumentu Mieszka I Plątonogiego (zm. 1211) dotyczącego kościoła św. Wojciecha we Wrocławiu.

3) Odpis dokumentu biskupa Wawrzyńca z 17 IV/1 V 1226 dotyczącego przejęcia przez tegoż biskupa kościoła św. Wojciecha od augustianów ${ }^{29}$. Na końcu autor dodał: „Littere originales omnium precedentium habentur in deposito conuentus" ${ }^{\prime 3}$.

4) Fragment ex cronicis fratrum (edycja tekstu w dalszej części artykułu) i nota końcowa: „Unde conuentus Wratislawiensis receptus est anno domini MCCXXVI ${ }^{\circ}$ kalendis Maii, ut colligi potest ex litteris prescriptis. Omnia ad laudem Dei et ad perpetuam rei memoriam".

5) Komentarz historyczny do dokumentu księcia Mieszka I Plątonogiego (nr 2), prawdopodobnie oparty na Kronice książą polskich. Na końcu tegoż komentarza, będącego zarazem ostatnim tekstem na k. 56v, autor napisał - jak to wyżej wspomniano - „Anno Domini 1481”.

${ }^{26}$ E. Balcerzowa, $X V$-wieczne polonica w zbiorach Państwowej Biblioteki Publicznej im. Saltykowa-Szczedrina w Leningradzie, „Studia z Filologii Polskiej i Słowiańskiej”, 29, 1991, s. 8-10.

${ }^{27}$ K. Kaczmarek, Szkoły i studia polskich dominikanów w okresie średniowiecza, Poznań 2005, s. 518-519; M. Zdanek, Szkoły i studia dominikanów krakowskich w średniowieczu, Warszawa 2005, s. 181. Warto też zauważyć, że imię Michała Rerera pojawia się kilkukrotnie w kodeksie petersburskim; Petersburg, Rosyjska Biblioteka Narodowa, rkps sygn. Lat. I F 212 , k. $37 \mathrm{v}, 38 \mathrm{r}, 50 \mathrm{v}, 127 \mathrm{r}, 128 \mathrm{v}$.

${ }^{28}$ KDŚl., t. 3, wyd. K. Maleczyński, Wrocław 1964, nr 330.

${ }_{29}$ Tamże, nr 326

${ }^{30}$ Co ciekawe, oba XIII-wieczne dokumenty biskupa Wawrzyńca (nr 1 i 3 ) zostały włączone również w korpus powstałego na przełomie lat 70. i 80. najstarszego żywota bł. Czesława; zob. Wrocław, Biblioteka Uniwersytecka, rkps sygn. IV Q 194, k. 5r-v; tamże, rkps sygn. IV F 184, k. IIIr-v. 
Dodajmy, że na następnych kartach (k. 57r-58v) odnajdujemy dwa teksty sporządzone inną ręką: odpis bulli Sykstusa IV Sacri praedicatorum z 1479 r. oraz umieszczoną pod rokiem 1484 formułę absolucji (k. $\left.58 \mathrm{v}^{\mathrm{a}-\mathrm{b}}\right)$. Możemy zatem przypuszczać, że teksty z k. 56v zapisano rzeczywiście na początku lat 80. XV w. Wydaje się, że autor tej „kolekcji historycznej” chciał przedstawić najważniejsze historyczne dokumenty związane z fundacją klasztoru wrocławskiego. Dostrzegł on w tych źródłach wyjątkowych i wiarygodnych ,świadków historii” wrocławskich dominikanów.

\section{Krytyka i edycja tekstu}

Dominikanin przygotowując „kolekcję historyczną”, ograniczył się do dwóch dokumentów biskupich i jednego książęcego oraz wypisu ex cronicis fratrum. Ewidentnie uznał te właśnie teksty za najgodniejsze wydobycia i zapamiętania. Przemilczał natomiast zupełnie opowieść o bł. Czesławie i początkach klasztoru wrocławskiego, podaną w XIV w. przez krakowskiego lektora Stanisława w Żywocie św. Jacka ${ }^{31}$. Być może wrocławski dominikanin dostrzegł - podobnie jak współczesny mu Jan Długosz zbyt wiele rozbieżności pomiędzy zebranymi przez siebie świadectwami a dziełem lektora Stanisława. Faktem jest, że przytoczone przez niego wypisy z dokumentów prezentowały odmienną, pod względem chronologicznym i faktograficznym, wersję początków miejscowej wspólnoty. W pierwszej kolejności przedstawię edycję XV-wiecznego fragmentu ex cronicis fratrum [dalej: $\left.\mathrm{CF}^{\mathrm{WR}}\right]^{32}$ :

Et aduerte, quod conuentus Cracouiensis susceptus est anno

Domini $\mathrm{MCCXXII}^{\circ}$ a fratre Jaczko, primo priore Cracouiensi,

misso illuc a magistro Jordano, successore san[c]ti

Dominici. Post hoc vero anno videlicet MCCXXV, frater

Gerardus Wratislauiensis, studens Parisius, per predictum magistrum

Jordanum prouincialis factus sine omni electione, Cracouiam

uenit et prouinciale capitulum fecit, de quo misit

fratres recipere domos: Wratislauiensem, Pragam,

Pomoraniam, Cassubiam et Sudumiriam. Ex cronicis fratrum.

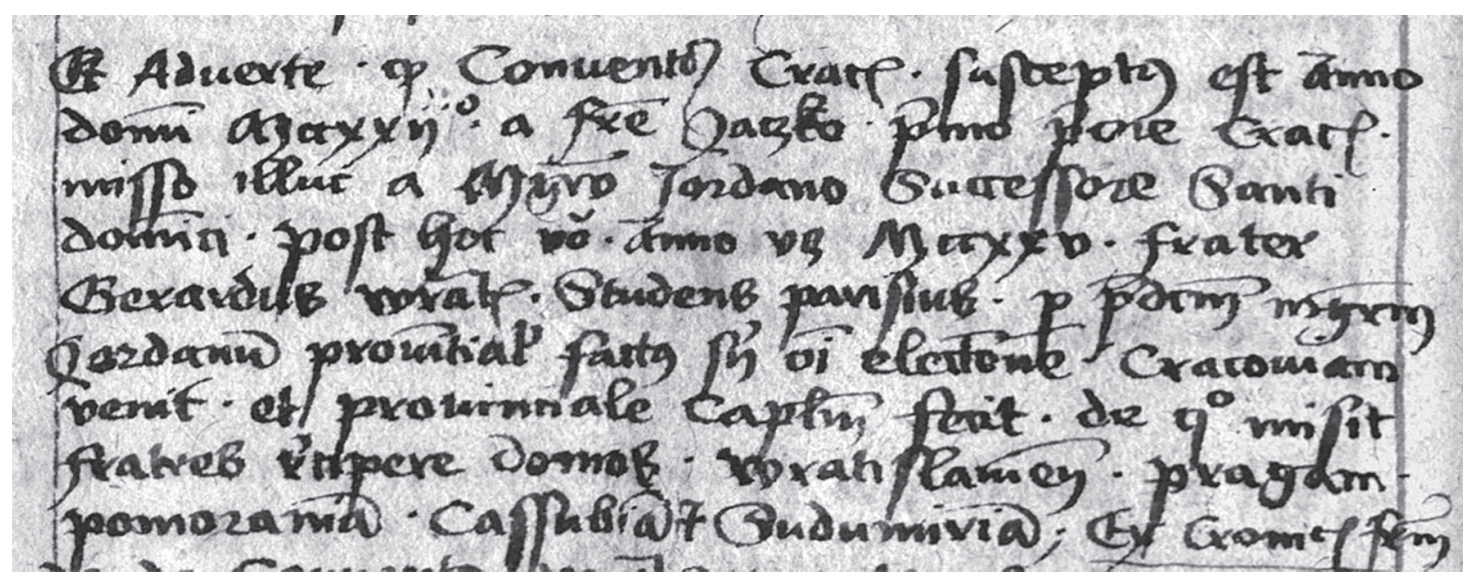

Il. 1. Petersburg, Rosyjska Biblioteka Narodowa, rkps sygn. Lat. I F 212, k. 56v (fragment)

${ }^{31}$ Lektor Stanisław z Krakowa, Życie i cuda, rozdz. 9, s. 113. Czytamy tam: „W roku Pańskim 1222 święty Jacek wysłał do Czech brata Czesława, [...] przybywszy z bratem Hieronimem do Pragi, otrzymali konwent pod wezwaniem św. Klemensa, [...] następnie przybyli do Wrocławia, gdzie wybudowali klasztor kaznodziejów na cześć św. Wojciecha. W tym też miejscu brat Czesław, jaśniejący niezliczonymi cudami, spoczął na wieki”.

32 Przy opracowaniu edycji kierowałem się zasadniczo projektem instrukcji wydawniczej A. Wolffa, Projekt instrukcji wydawniczej dla pisanych źródet historycznych do połowy XVI wieku, St. Źródł., 1, 1957, s. 155-181. W edycji zachowałem oryginalny podział na wiersze i rozróżnienie na „u” i „v". 
Lektura $\mathrm{CF}^{\mathrm{WR}}$ nie pozostawia wątpliwości, że mamy do czynienia z poprawnie skomponowaną narracją rocznikarską. Autorowi udało się w syntetyczny sposób wskazać kilka kluczowych elementów w relacji o początkach zakonu dominikańskiego w Polsce. Łatwo zauważyć, że ten tekst jest w niektórych częściach identyczny z treścią cytowanej już wyżej noty z Długoszowego katalogu prowincjałów dotyczącej prowincjała Gerarda i tzw. rozesłania krakowskiego. Należy jednak odrzucić możliwość, że XV-wieczny dominikański autor miał przed oczyma dzieło Długosza i umiejętnie je streścił, a kilka zdań wprost skopiował. Nie chodzi tylko o to, że trudno jest domniemywać, by któryś z wrocławskich dominikanów na początku lat 80. miał bezpośredni dostęp do tekstu $\mathrm{LB}^{33}$. Najistotniejszy jest fakt, że sam dominikański autor podał wyłącznie jeden odsyłacz źródłowy: ex cronicis fratrum, informując w ten sposób czytelnika, że przytoczony fragment nie jest jego autorską kreacją, a jedynie został przez niego zaczerpnięty z innego dzieła.

Zagadnienie relacji pomiędzy $\mathrm{CF}^{\mathrm{WR}}$ a Długoszem staje się lepiej widoczne, gdy zestawimy oba źródła.

\begin{tabular}{|c|c|c|}
\hline $\begin{array}{l}\mathrm{CF}^{\mathrm{WR}}=\text { Cronicae fratrum } \mathrm{z} \text { rękopisu } \\
\text { petersburskiego }\end{array}$ & $\begin{array}{l}\text { LB = J. Dlugosz, Liber beneficiorum, } \\
\text { t. 3, s. 449-450 }\end{array}$ & $\begin{array}{l}\text { VAC }=\text { Vita antiqua beati Ceslai } \\
\left(\mathrm{W}^{1}=\text { BUWr., rkps IV F 184, k. IIIv } ;\right. \\
\left.\mathrm{W}^{2}=\text { BUWr., rkps IV Q 194, k. } 4 \mathrm{r}^{\mathrm{b}}-\mathrm{v}^{\mathrm{a}}\right)\end{array}$ \\
\hline 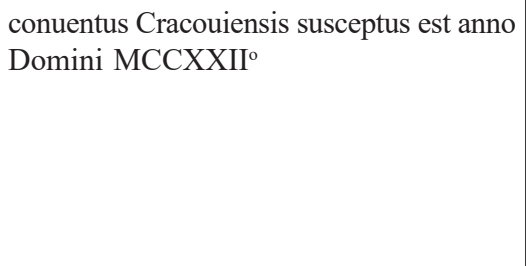 & $\begin{array}{l}{[\text { brak w LB daty rocznej przybycia }} \\
\text { dominikanów do Krakowa }]\end{array}$ & $\begin{array}{l}\text { Frater Ceslaus atque Iacintus (Hyacinthus } \\
\mathrm{W}^{2} \text { ) Poloniam redeuntes Cracoviam } \\
\text { tandem pervenerunt ubi a clero et } \\
\text { populo honorifice suscepti ecclesiam } \\
\text { Sancte Trinitatis obtinuerunt apud quam } \\
\text { conventum fundaverunt anno Domini } \\
\text { MCCXXII }\end{array}$ \\
\hline a fratre Jaczko, primo priore Cracouiensi & $\begin{array}{l}\text { Primusque loci illius prior fuit Hyacintus } \\
\text { alias Jaczko [...] }\end{array}$ & $\begin{array}{l}\text { ubi et primus prior extitit dictus frater } \\
\text { Jacinctus (Hyacinthus } \mathrm{W}^{2} \text { ) }\end{array}$ \\
\hline- & $\begin{array}{l}\text { in ordine praedicto vitam monasticam et } \\
\text { religiosam ducens, stupendis miraculis, } \\
\text { tam in vita, quam in }[\ldots] \text { moribus claruit }\end{array}$ & $\begin{array}{l}\text { ac tandem vitae cursu laudabili } \\
\text { peracto virtutibus plenus et prodigijs } \\
\text { miraculorumque tam in vita quam in } \\
\text { morte clarus }[\ldots]\end{array}$ \\
\hline $\begin{array}{l}\text { misso illuc a magistro Jordano, successore } \\
\text { sancti Dominici. }\end{array}$ & - & - \\
\hline $\begin{array}{l}\text { Post hoc vero anno videlicet MCCXXV, } \\
\text { frater Gerardus Wratislauiensis, studens } \\
\text { Parisius, per predictum magistrum } \\
\text { Jordanum prouincialis factus sine omni } \\
\text { electione, }\end{array}$ & $\begin{array}{l}\text { Frater Gerardus nacione Polonus in } \\
\text { provincionalem, per magistrum generalem } \\
\text { ordinis praedicatorum Jordanum, } \\
\text { crescente religione praedicta in regno } \\
\text { Poloniae, anno Domini } 1225 \text { praefectus } \\
\text { est [...] } \\
\text {------------------------- } \\
\text { Frater Gerardus nacione Wratislauiensis, } \\
\text { studens Parisiensis, primus provincialis } \\
\text { Polonie, per Jordanum magistrum } \\
\text { generalem Ordinis Praedicatorum } \\
\text { praeficitur anno 1225, absque omni } \\
\text { fratrum electione, }\end{array}$ & $\begin{array}{l}\text { successor eius [scil. Dominici] Magister } \\
\text { Jordanis recepit ad ordinem Parisius } \\
\text { fratrem Gerardum de Wratislavia } \\
\text { studentem, quem postmodum professione } \\
\text { in ordine facta priorem provincialem sine } \\
\text { tamen omni electione praehabita instituit, }\end{array}$ \\
\hline $\begin{array}{l}\text { Cracouiam uenit et prouinciale capitulum } \\
\text { fecit, }\end{array}$ & $\begin{array}{l}\text { hic Cracouiam veniens, primum ibi } \\
\text { celebravit capitulum, }\end{array}$ & $\begin{array}{l}\text { et eundem denique Cracoviam misit, } \\
\text { ubi in capitulo provinciali primo inibi } \\
\text { celebrato fuit iniunctus. }\end{array}$ \\
\hline $\begin{array}{l}\text { de quo misit fratres recipere domos: } \\
\text { Wratislauiensem, Pragam, Pomoraniam, } \\
\text { Cassubiam et Sudumiriam. }\end{array}$ & $\begin{array}{l}\text { de quo misit fratres recipere domos: Vra- } \\
\text { tislauiensem, Pragensem, Camnenensem, } \\
\text { Sandomiriensem, }<\text { Gdanensem }>\end{array}$ & - \\
\hline
\end{tabular}

33 Przypomnę, że trzecia część tego monumentalnego dzieła, zawierająca interesujący nas fragment, powstała prawdopodobnie w latach 1474-1476. Długosz pracował nad księgą uposażeń do samej śmierci w 1480 r.; zob. M.D. Kowalski, Źródła $i$ wiarygodność informacji $w$,Liber beneficiorum dioecesis cracoviensis” Jana Dlugosza, w: Jan Dlugosz (1415-1480). Życie i dzieła, red. L. Korczak, M.D. Kowalski, P. Węcowski, Kraków 2016, s. 105. 
W LB nie zaznaczono daty rocznej przybycia dominikanów do Krakowa, a dopiero fakt przejęcia przez nich kościoła Świętej Trójcy w 1223 r., choć należy pamiętać, że w Rocznikach Długosz odnotował przybycie dominikanów do Krakowa i objęcie kościoła pod rokiem 1222, niewątpliwie na podstawie zapiski w Roczniku kapituły krakowskiej ${ }^{34}$. Kronikarz nie podał również żadnych informacji o udziale drugiego generała Zakonu, Jordana z Saksonii, w posłaniu Jacka. Natomiast w obu źródłach powtarza się wiadomość o św. Jacku jako pierwszym przeorze konwentu krakowskiego. W przypadku informacji o prowincjale Gerardzie wyraźnie widoczne jest podobieństwo między fragmentem w LB a CFWR. Występuje niemal identyczna struktura tekstu oraz odnajdujemy te same wiadomości na temat pochodzenia Gerarda, jego studiów w Paryżu, mianowaniu na polskiego prowincjała przez generała Jordana, posłaniu go do Krakowa, organizacji przez niego kapituły oraz posłaniu w celu założenia klasztorów. Wynika z tego, że Jan Długosz i wrocławski dominikanin, autor $C F^{\mathrm{WR}}$, korzystali z tego samego źródła (lub z bardzo bliskich sobie redakcji tego samego źródła). Istniejące różnice między LB i CFWR można dość łatwo wyjaśnić. Pominięcie informacji o posłaniu Jacka przez generała Jordana z Saksonii mogło wynikać z jej sprzeczności z obowiązującą już w XV w. tradycją, przyjętą za lektorem Stanisławem, o wysłaniu brata Jacka przez samego św. Dominika. Różne są też nazwy domów zakonnych użyte w dziele Długosza. Najpewniej w wykorzystanym przez niego źródle był zapis w wersji zbliżonej do $\mathrm{CF}^{\mathrm{WR}}$, czyli „Pomoraniam, Cassubiam”, lecz autor LB zidentyfikował te dwa klasztory zlokalizowane na Pomorzu i Kaszubach, określając je jako: „Camnenensis, Gdanensis”. Ewidentnie dziejopis starał się samodzielnie zredagować listę pierwszych klasztorów w polskiej prowincji, dlatego na marginesie LB został dopisany jeszcze dom w Gdańsku.

W celach porównawczych do tych rozważań warto wprowadzić jeszcze jedno przywołane w tabeli źródło z XV w., a mianowicie Vita antiqua bł. Czesława [dalej: VAC]. Autorem tego tekstu był zapewne Marcin Kestner OP (zm. ok. 1498) ${ }^{35}$, działający we Wrocławiu w tym samym czasie, co zakonnik, który przytoczył fragment ex cronicis fratrum. W VAC przywołana została opowieść o św. Jacku i o pierwszym prowincjale Gerardzie. Zestawienie tego fragmentu z tekstami $\mathrm{CF}^{\mathrm{WR}}$ i LB prowadzi do kolejnych wniosków.

Porównanie LB z VAC wskazuje na pewne podobieństwa między nimi, z których najwyraźniejsze występuje we fragmencie mówiącym o świętości i cudach św. Jacka „tak za życia jak i po śmierci”. Uwagę zwraca też brak w LB i VAC informacji o posłaniu Jacka przez generała Zakonu Jordana. Inne, drobniejsze podobieństwa między LB i VAC, różniące zarazem te utwory od $\mathrm{CF}^{\mathrm{WR}}$, to podkreślenie, że kapituła zorganizowana przez prowincjała Gerarda była „pierwsza” i była nie tyle „zrobiona”, jak podaje $\mathrm{CF}^{\mathrm{WR}}$ (capitulum fecit), co celebrowana: celebravit (LB) / celebrato (VAC). Podanie przez Długosza i autora VAC formy imienia Hyacinthus (LB) i Jacintus / Hyacinthus (VAC) wynika zapewne z faktu, że zlatynizowana forma, której twórcą i popularyzatorem był lektor Stanisław, była bardziej „elegancka”, a za sprawą Żywota św. Jacka od drugiej połowy XIV w. stała się oficjalnym imieniem pierwszego polskiego dominikanina. W LB zostały zresztą przytoczone obie formy (Hyacintus alias Jaczko), co wskazuje, że w źródle wykorzystanym przez Długosza musiała występować starsza forma imienia: „Jaczko”. Wymienione wyżej podobieństwa nie dają podstaw, by twierdzić, że informacje w LB zostały zaczerpnięte z VAC. Długosz musiał korzystać z jakiegoś niezależnego od VAC źródła, czego najlepszym dowodem jest obecność w LB ostatniego fragmentu mówiącego o rozesłaniu braci, a pominiętego w VAC. Marcin Kestner, nawet jeżeli miał dostęp do fragmentu mówiącego o rozesłaniu i powstaniu sześciu klasztorów, to przeredagował go i wspomniał tylko o założeniu klasztoru wrocławskiego przez Czesława. Należy również odrzucić możliwość, by autor VAC miał dostęp do LB. Najprawdopodobniej zatem autorzy LB i VAC skorzystali z jednego wspólnego źródła, które roboczo określę źródłem $\Omega$.

${ }^{34}$ Ioannis Dlugossii Annales seu Cronicae incliti Regni Poloniae, lib. 5-6, wyd. D. Turkowska, K. Pieradzka i in., Warszawa 1973 , s. 234-235.

${ }^{35}$ K. Kaczmarek, Szkoty i studia polskich dominikanów, s. 511; W. Kucharski, „Beatus Ceslaus natione Polonus”. Dzieje kultu błogosławionego Czesława, Studia i Źródła Dominikańskiego Instytutu Historycznego w Krakowie, t. 10, Kraków 2012, s. 99-102. Warto też zauważyć, że imię Marcina Kestnera pojawia się kilkukrotnie w kodeksie petersburskim; Petersburg, Rosyjska Biblioteka Narodowa, rkps sygn. Lat. I F 212, k. 3v, 41v, 51v, 54v. 
Jak sądzę, źródło $\Omega$ zapewne znajdowało się w zbiorach dominikańskiego klasztoru we Wrocławiu. W przypadku VAC jest w pełni zrozumiałe, że dominikanin Marcin Kestner, pisząc o pierwszym przeorze wrocławskim, sięgnął do archiwaliów przechowywanych na miejscu (archiwum, biblioteka, zakrystia). Co zaś tyczy się Jana Długosza, wiemy, że przebywał on we Wrocławiu w czerwcu 1466 r., prawie cały grudzień $1467 \mathrm{r}$. i ponownie krótko na początku lutego $1468 \mathrm{r}^{36}$ Przypuszczalnie wtedy właśnie sporządził dla siebie odpis źródła $\Omega$. Kilka lat później skorzystał z niego w trakcie przygotowywania opowieści o początkach klasztoru krakowskiego, a zwłaszcza katalogu prowincjałów. Najprawdopodobniej źródło $\Omega$ jest tożsame z nieznanym pierwowzorem $\mathrm{CF}^{\mathrm{WR}}$, z którego skorzystał ok. $1481 \mathrm{r}$. wrocławski autor, sporządzając wypis ex cronicis fratrum. W świetle przeprowadzonych analiz możemy zatem sformułować wysoce prawdopodobną hipotezę, że XV-wieczne teksty $\mathrm{CF}^{\mathrm{WR}}$, LB i VAC, dotyczące początków dominikanów polskich, pochodzą bezpośrednio od jednego źródła $\Omega^{37}$, będącego pierwotną relacją o najstarszych dziejach polskiej gałęzi Zakonu Kaznodziejów.

Na koniec rozważań w tej części powiedzmy jeszcze kilka słów o relacji źródła $\Omega$ do tekstu Żywota św. Jacka autorstwa lektora Stanisława. Co ciekawe, nie odnajdujemy żadnych wyraźnych podobieństw pomiędzy tymi źródłami. Lektor Stanisław jako datę przybycia zakonników do Krakowa podał 1217 r., nie wspomniał, że Jacek był pierwszym przeorem, pominął informacje o Gerardzie z Wrocławia i pierwszej kapitule prowincjalnej, brak również w jego dziele wzmianki o Sandomierzu i Kaszubach. Co więcej, według lektora to sam św. Dominik posłał św. Jacka do Polski, na temat zaś Jordana z Saksonii krakowski dominikanin milczał. Najprawdopodobniej zatem autor Żywota św. Jacka w ogóle nie znał źródła $\Omega$. Czyżby więc znajdowało się ono wyłącznie w klasztorze wrocławskim? Kwestia ta musi na razie pozostać nierozstrzygnięta.

\section{Czas powstania źródła $\Omega$}

Wiemy już, że wrocławski pisarz przygotowując „kolekcję historyczną” znajdującą się na k. 56v rękopisu z Petersburga, wybrał najstarsze źródła dotyczące miejscowej wspólnoty. Pominął natomiast XIV-wieczny Żywot św. Jacka autorstwa lektora Stanisława oraz XV-wieczny Żywot bt. Czesława. Można zatem przypuszczać, że źródło $\Omega$, podobnie jak przytoczone książęce i biskupie litterae originales, miało XIII-wieczną metrykę. Na tak wczesną datację źródła $\Omega$ wskazują dwie następujące obserwacje.

Źródło $\Omega$ - jak przekazał tekst $\mathrm{CF}^{\mathrm{WR}}$ - zawierało informacje o posłaniu brata Jacka przez drugiego generała zakonu, bł. Jordana z Saksonii ${ }^{38}$. Obecność tego właśnie generała nie jest zaskoczeniem w kontekście najstarszych dziejów zakonu, natomiast stoi w sprzeczności z późniejszą tradycją, promowaną przez lektora Stanisława i w XV w. powszechnie przyjętą przez polskich dominikanów, o posłaniu pierwszych braci przez samego św. Dominika. Trudno zatem przypuszczać, by jakikolwiek autor z XIV w., a zwłaszcza z XV w., „odważył się” podać w wątpliwość i zmienić obowiązującą narrację. Można zaryzykować stwierdzenie, że autor źródła $\Omega$ świadomie chciał zaakcentować rolę Jordana w dziejach pierwszego konwentu dominikańskiego na ziemiach polskich. To właśnie w XIII w. Jordan cieszył się

\footnotetext{
${ }^{36}$ A. Perzanowska, Wiadomości źródłowe o życiu i działalności Jana Dlugosza, w: Dlugossiana. Studia historyczne w pięćsetlecie śmierci Jana Dlugosza, red. S. Gawęda, Zeszyty Naukowe Uniwersytetu Jagiellońskiego, t. 561, Prace Historyczne, z. 65, Kraków 1980, s. 337, 340-343; S. Solicki, Kontakty osobiste Jana Dlugosza z Czechami, „Acta Universitatis Wratislaviensis”, 70, 1968, s. 160-162; W. Kucharski, „Beatus Ceslaus natione Polonus”, s. 89, 91-92. Być może odpis tego źródła został sporządzony przez któregoś z wielu śląskich przyjaciół Jana Długosza; zob. W. Szelińska, Śląsk w piśmiennictwie Jana Dlugosza, Kraków 1993, s. 57.

${ }^{37}$ Nie można całkiem wykluczyć - choć wydaje się to mało prawdopodobne - że istniało jeszcze jakieś ogniwo pośrednie pomiędzy źródłem $\Omega$ a LB i VAC (nazwijmy ten przekaz źródłem $\alpha$ ), stanowiące wspólne źródło relacji o początkach dominikanów polskich znajdujących się w LB i VAC. Argumentem za istnieniem redakcji $\alpha$ byłby fragment o świętości i cudach św. Jacka „tak za życia, jak i po śmierci”, tak podobnie brzmiący w dziełach Długosza i Marcina Kestnera. Możliwe jednak, że mamy tu do czynienia po prostu z konwencją literacką właściwą średniowiecznym tekstom hagiograficznym, przyjętą również przez autorów LB i VAC. Wyjaśnienie to jest o tyle prawdopodobne, że od drugiej połowy XV w. obserwujemy wzrost kultu św. Jacka.

${ }^{38}$ Więcej na ten temat piszę w artykule: Przybycie św. Jacka do Krakowa w 1222 roku w świetle nowego źródła (w przyg.).
} 
nie tylko sławą, ale po tragicznej śmierci w 1237 r. również kultem wśród dominikanów. Jednak już w XIV i XV w. jego postać powoli zaczęła znikać w cieniu innych wielkich świętych z Zakonu Kaznodziejów. Lektor Stanisław w drugiej połowie XIV w. w ogóle o nim nie wspomniał, a Jan Długosz w LB krótko poinformował, że w czasach pierwszego polskiego prowincjała Gerarda generałem zakonu był Jordan, jednak bez wskazania jego narodowości, kolejności na liście generałów i dodatkowego opisu, np. wzmianki, że był on następcą św. Dominika.

Hipoteza o XIII-wiecznej metryce źródła $\Omega$ znajduje potwierdzenie w jeszcze jednej obserwacji. W końcowej części CFWR , w wykazie miejscowości, do których mieli udać się bracia, by założyć klasztory, wymieniony został Sandomierz zapisany jako Sudumiria. W źródłach średniowiecznych nazwa tego miasta pojawia się w kilku różnych formach. W najstarszych świadectwach z XII w. najczęściej występuje ono jako Zadomir $(1148)^{39}$, Sudomir $(1166)^{40}$ i Sumdemiria $(1198)^{41}$. W XIII w. pojawiły się formy Sodomiria (1223), Sudomiria (1228), Sundomiria (1232), Sudomeria (1235) i Zandomiria (1239) ${ }^{42}$. Dodajmy, że nazwa Sudomiria występuje powszechnie w XIII-wiecznej Kronice halicko-wołyńskiej ${ }^{43}$. Od 1228 r. w źródłach dyplomatycznych, rocznikarskich i narracyjnych używana jest najczęściej forma Sandomiria ${ }^{44}$. Takie określenie występuje zarówno we wszystkich tekstach autorstwa Jana Długosza, jak i w innych XV-wiecznych rocznikach, kronikach, katalogach i kalendarzach. Powyższe zestawienie należy uzupełnić o jeszcze jedną postać nazwy Sandomierza, a mianowicie Sudumiria, a więc wersję taką jak w $\mathrm{CF}^{\mathrm{WR}}$. Nazwę w tym brzmieniu dotychczas udało się odnaleźć w czterech dokumentach z lat 1217-1232 dotyczących spraw majątkowych bożogrobców z małopolskiego Miechowa ${ }^{45}$. Widzimy więc, że ta ostatnia wersja nazwy Sandomierza pojawiła się w ściśle określonym przedziale czasowym i w ograniczonym środowisku. Występująca w $\mathrm{CF}^{\mathrm{WR}}$ forma Sudumiria, niewątpliwie przejęta ze źródła $\Omega$, jest więc archaiczną wersją nazwy Sandomierza, która funkcjonowała w pierwszej połowie XIII w. Pozwala to przyjąć czas powstania źródła $\Omega$ na lata 30 . XIII w., niedługo po ustabilizowaniu się fundacji.

\section{Autorstwo}

Należy jeszcze zastanowić się nad zagadnieniem autorstwa źródła $\Omega$. Oczywiście zachowany fragment $\left(\mathrm{CF}^{\mathrm{WR}}\right)$ nie pozwala na jednoznaczną identyfikację autora, jednak dostarcza on nowej argumentacji wzmacniającej hipotezę M. Zdanka. Przypomnę, że według krakowskiego historyka jednym z autorów interesującego nas źródła mógł być dominikanin Marcin z Sandomierza ${ }^{46}$. Brat Marcin należał do pierwszego pokolenia polskich braci kaznodziejów. Uczestniczył on wraz z prowincjałem Gerardem i przeorem Jackiem w kapitule generalnej (1228). Był również przeorem płockim $(1239,1257)$ i raciborskim (1267) oraz polskim prowincjałem w latach 1244-1247. O ścisłej współpracy Marcina z Jackiem świadczy jego udział w misji ruskiej i pruskiej ${ }^{47}$. M. Zdanek hipotezę oparł przede wszystkim na analizie katalogu prowincjałów z LB oraz na innych zapiskach w Rocznikach Długosza na temat polskich dominikanów. W konkluzji badacz ten stwierdził, że Marcin z Sandomierza ,jawi się jako jeden

39 Stownik geograficzny Królestwa Polskiego i innych krajów słowiańskich, t. 10, red. B. Chlebowski, W. Walewski, według planu F. Sulimierskiego, Warszawa 1889, s. 268.

${ }^{40}$ KDKK, t. 1, wyd. F. Piekosiński, Kraków 1874, nr 1; zob. inne przykłady: S. Tabaczyński, A. Buko, Sandomierz: starożytność, wczesne średniowiecze, Rzeszów 1982, s. 181-182. Na temat etymologii nazwy Sandomierz zob. T. Lalik, Sandomierz w świetle źródet pisanych, w: Sandomierz: badania 1969-1973, t. 1, red. S. Tabaczyński, Warszawa 1993, s. 53-54; A. Buko, Początki Sandomierza, Warszawa 1998, s. 47-52.

${ }^{41}$ KDMłp., t. 2, wyd. F. Piekosiński, Kraków 1886, nr 375, 376.

42 Tamże, nr 388, 399, 403, 412, 417; KWlkp., t. 1, wyd. I. Zakrzewski, Poznań 1877, nr 123.

${ }^{43}$ Kronika halicko-wołyńska (Kronika Romanowiczów), wyd., wstęp i przyp. D. Dąbrowski, A. Jusupović, współpr. I. Juriewa, A. Majorow, T. Wiłkuł, w: MPH s.n., t. 16, Kraków-Warszawa 2017, np. s. 236, 622 (zob. aparat filologiczny).

${ }^{44}$ KDMłp., t. 2, nr 395, 423, 476, 498, 499, 581; Rocznik kapituły krakowskiej, wyd. Z. Kozłowska-Budkowa, w: MPH s.n., t. 5, Warszawa 1978, s. 88,100 .

45 KDMłp., t. 2, nr 384, 391, 392, 404.

${ }^{46}$ M. Zdanek, ,Zaginiona kronika dominikańska”, s. 282.

47 J. Kłoczowski, Marcin z Sandomierza, s. 570-571; M. Zdanek, Szkoty i studia dominikanów krakowskich, s. 58. 
z możliwych autorów - a przynajmniej informatorów - części not rocznikarskich"48. Jak wykazano wyżej, źródło $\Omega$ powstało w latach 30. XIII w., a nazwa Sandomierza w brzmieniu Sudumiria występuje w dokumentach miechowskich z lat 1217-1232 i używana była przez małopolskich pisarzy. Można więc przypuszczać, że autor źródła $\Omega$ również żył i działał w tym właśnie czasie oraz należał do grupy dominikanów pochodzących z Małopolski. Nie ulega wątpliwości, że brat Marcin, który wstapił do zakonu w latach 20. XIII w. i był związany z Sandomierzem, spełnia warunki, aby uchodzić za możliwego twórcę źródła $\Omega$, z którego pochodzi zapiska w $\mathrm{CF}^{\mathrm{WR}}$.

\section{Kilka uwag o formie źródła $\Omega$}

Niezwykle istotne jest znalezienie odpowiedzi na pytanie, czym było źródło $\Omega$ określone w kompilacji z końca XV w. jako cronicae fratrum. Powiedzmy od razu, że trudno jest doszukiwać się w tych „kronikach braci” jakiegoś precyzyjnego tytułu lub konkretnej formy dzieła. Pod tą nazwą mogła kryć się zarówno jedna zwarta kronika, rocznik, nekrolog czy lista prowincjałów, jak i grupa najstarszych dokumentów przechowywanych przez samych zakonników. G. Labuda był przekonany, że „owo zaginione źródło wprawdzie nie pozbawione elementów chronologii, swoją formą zewnętrzną bardziej zbliżało się do kroniki niż do rocznika"49. Z kolei J.A. Spież widział w tym „zaginionym źródle” nawet coś więcej niż kronikę. Według niego polscy dominikanie posiadali dzieło podobne do Libellus de principiis Ordinis autorstwa drugiego dominikańskiego generała Jordana z Saksonii ${ }^{50}$. Należy jednak pamiętać, że hipotezy obu tych historyków nie wytrzymały próby czasu. M. Zdanek wolał mówić raczej o roczniku niż kronice, ale również zgodził się, że „w swojej partii początkowej wykazuje cechy mniej schematycznego opowiadania o początku zakonu w Polsce" ${ }^{51}$. Już po pobieżnej lekturze $\mathrm{CF}^{\mathrm{WR}}$ staje się jasne, że zapiska ta nie pochodzi ani z ,typowego” rocznika, podobnego np. do Rocznika kapituly krakowskiej, ani z kroniki narracyjnej wzorowanej choćby na dziele Mistrza Wincentego Kadłubka. Poszukując analogii dla analizowanego tekstu, warto zwrócić uwagę na średniowieczny przykład dziejopisarstwa dominikańskiego, jakim jest niewielka kronika (w edycji jej tekst zajmuje zaledwie 1,5 strony) zatytutowana Historia Ordinis Praedicatorum in Dacia ${ }^{52}$.

Kronika ta obejmuje lata 1221-1246 i opisuje działalność dominikanów na terenach Danii i Skandynawii ${ }^{53}$. Tekst powstał ok. 1261 r., aczkolwiek nie można wykluczyć, że pierwsza część kroniki została spisana już w 1237 r. ${ }^{54}$ Historia jest narracją kronikarską i składa się z trzech części. Pierwsza rozpoczyna się od informacji o powstaniu zakonu w 1216 r., a kończy relacją o założeniu w 1222 r. pierwszego klasztoru prowincji Dacji w Lund i wyborze pierwszego przeora. Głównym bohaterem pierwszej części jest brat Salomon z Århus (de Arhusia). W trakcie lektury można odnieść wrażenie, że dominikański autor skomponował swego rodzaju Vita sancti Salomonis. Pojawia się choćby opowiadanie o nadprzyrodzonej wizji św. Dominika, jakiej doświadczył Salomon w czasie niebezpiecznej podróży z Flandrii do Danii. Święty Dominik miał w niej „podtrzymać własnymi ramionami” statek, którym płynął Salomon, i w ten sposób cudownie uchronić go od zatonięcia podczas burzy ${ }^{55}$. Druga i zarazem najkrótsza

${ }^{48}$ M. Zdanek, „Zaginiona kronika dominikańska”, s. 282

49 G. Labuda, Zaginiona kronika, s. 160.

50 J.A. Spież, Początki dominikanów, s. 81.

${ }_{51}$ M. Zdanek, „Zaginiona kronika dominikańska”, s. 281.

${ }^{52}$ Najnowsza edycja tego źródła: cz. 1: S. Tugwell, Notes on the Life of St Dominic (1), „Archivum Fratrum Praedicatorum”, 66, 1996, s. 162-164; cz. 2: tenże, The Evolution of Dominican Structures of Government, „Archivum Fratrum Praedicatorum”, 70, 2000, s. 87; cz. 3: tenże, Notes on the Life of St Dominic (2), „Archivum Fratrum Praedicatorum”, 68, 1998, s. 111-112.

53 Provincia Daciae powstała niemal w tym samym czasie, co provincia Poloniae i w precedencji najstarszych 12 prowincji zakonu sytuowała się zaraz po Polsce; zob. P.B. Halvorsen, Dominikus: en europeers liv på 1200-tallet, Oslo 2002, s. 218-220; J. Grandjean Gøgsig Jakobsen, „, Venerunt fratres praedicatores”. Notes on Datings of the First Dominican Convent Foundations in Scandinavia, „Collegium Medievale”, 24, 2011, s. 5-22.

${ }^{54}$ S. Tugwell, Notes on the Life of St Dominic (1), s. 161.

55 Tamże, s. 163-164. 
część Historiae została ściśle powiązana z pierwszą. Po informacji o ustanowieniu pierwszego przeora autor przedstawił historię nominacji w 1225 lub 1226 r. pierwszego prowincjała prowincji Dacji, którym został brat Rano (Ranoldus), oraz wspomniał o jego dwóch następcach. Fragment ten ma formę katalogu prowincjałów. Trzecia część dotyczy (pierwszego) założenia konwentu w Tallinie ok. 1229 r. oraz kapituły prowincjalnej odprawionej w $1246 \mathrm{r}$.

Nie ulega wątpliwości, że wspomniana Historia stanowi ciekawy przykład XIII-wiecznej kroniki zakonnej opisującej dzieje jednej prowincji. Co więcej, rzuca ona nowe światło na źródła dotyczące polskich dominikanów. Dotychczas bowiem historycy nie zwrócili uwagi na podobieństwa pomiędzy Historia Ordinis Praedicatorum in Dacia a opisami początków polskich dominikanów, jakie przedstawili lektor Stanisław i Jan Długosz w LB. Zauważmy, że struktura opowieści biograficznej braci Salomona i Jacka jest w wielu punktach zaskakująco zbieżna i nie chodzi wyłącznie o fakt, że obaj - choć nie zostali prowincjałami - funkcjonowali jako „ojcowie założyciele”56. Zwróćmy uwagę na siedem najbardziej rzucających się w oczy podobieństw: 1) inicjatywa sprowadzenia dominikanów do Polski i Skandynawii pochodziła ze strony duchowych świeckich, którzy w trakcie pobytu w Rzymie spotkali św. Dominika i zwrócili się do niego z bezpośrednią prośbą o przysłanie braci; 2) obaj uczestniczyli w reformie klasztoru we Fryzaku; 3) w trakcie misji towarzyszył im brat konwers; 4) mieli oni nadprzyrodzone doświadczenie w trakcie przeprawy przez wodę; 5) zostali przyjęci przez lokalnego biskupa, któremu przedstawili odpowiednie dokumenty papieskie; 6) biskup Lund przyjął Salomona i „edificia fratribus apta construxit" ${ }^{57}$, biskup krakowski zaś podobnie przyjął Jacka ,in aedicula ad hoc specialiter aedificata"58; 7) brat Salomon spotkał się w 1222 r. w Lund z kardynałem Grzegorzem Krescencjuszem, a brat Jacek spotkał tegoż kardynała w 1223 r. Krakowie.

Można się zastanawiać, czy źródło $\Omega$, z którego skorzystał w XV w. wrocławski dominikanin, nie tylko było podobne do kroniki braci z prowincji Dacji, ale również ,genealogicznie” z tą kroniką powiązane. Wiadomo, że średniowieczni dominikanie mieli wiele okazji, np. podczas corocznych kapituł generalnych, by wymieniać się informacjami i tekstami, opowieściami o początkach ich prowincji. Nie byłoby zatem czymś szczególnie dziwnym, gdyby polscy zakonnicy znali dzieje braci z sąsiednich prowincji i mieli dostęp np. do Historia Ordinis Praedicatorum in Dacia. Może więc zaginione źródło $\Omega$ było inspirowane kroniką dominikanów z prowincji Dacji, a może było na odwrót i biografie obu braci, Jacka i Salomona, wzajemnie się uzupełniają i przenikają? Albo odnaleziony w Petersburgu tekst stanowi fragment jakiejś zaginionej Historiae Ordinis Praedicatrum in Polonia, opowiadającej podobnie jak Historia Ordinis Praedicatorum in Dacia - o okolicznościach przybycia dominikanów do tej części Europy? Odpowiedź na powyższe pytania wymaga osobnego studium.

\section{Znaczenie zapiski dla badania najstarszych dziejów dominikanów w Polsce}

Tekst $\mathrm{CF}^{\mathrm{WR}}$, choć jest niewielkiej objętości, zawiera cenne informacje. Analizie jego zawartości poświęcam osobne teksty ${ }^{59}$, w tym miejscu zaś chciałbym tylko zasygnalizować najważniejsze obserwacje i wnioski odnoszące się do najstarszych dziejów polskich dominikanów. Odnaleziony fragment ostatecznie przecina spekulacje na temat czasu przybycia św. Jacka do Krakowa, który niewątpliwie

\footnotetext{
56 Podobieństwa pomiędzy biografiami brata Salomona i brata Jacka zauważyli już J. Grandjean Gøgsig Jakobsen i B.A. Wileniec Sønderby. Zgłosili oni m.in. postulat re-opening of the case związków Jacka z prowincją Dacji; zob. J. Grandjean Gøgsig Jakobsen, Św. Jacek i Dacja. Związki Apostoła Pólnocy ze Skandynawią: prawdopodobieństwo, tradycja i aktualny stan wiedzy, w: Św. Jacek Odroważ. Apostoł Pótnocnej Europy. Międzynarodowe sympozjum, Papieski Uniwersytet św. Tomasza z Akwinu „Angelicum”, Aula Jana Pawła II, Rzym, 16 października 2007 r., red. A. Nocoń, A. Wuwer, Roma-Katowice 2012, s. 97-109; B.A. Wileniec Sønderby, Św. Jacek w Skandynawii: misja czy fikcja?, w: tamże, s. 110-123.

57 S. Tugwell, Notes on the Life of St Dominic (1), s. 164.

58 LB, s. 449.

59 T. Gałuszka, Przybycie św. Jacka do Krakowa w 1222 roku świetle nowego źródła (w przyg.); tenże, Pierwsza kapituła prowincjalna dominikanów polskich w 1225 roku (w przyg.).
} 
został posłany do Polski w 1222 r. Data ta jest zgodna z przekazem Rocznika kapituly krakowskiej. Warto zauważyć, że oba źródła, zgodnie podające ten sam rok, ukazują zarówno „wewnętrzną” perspektywę dominikańską, jak i spojrzenie ,z zewnątrz”. Oczywiście nie wiemy, czy przybycie św. Jacka do Krakowa było tożsame z „oficjalnym” przybyciem dominikanów do metropolii gnieźnieńskiej, ale zapewne tak właśnie było.

Dowiadujemy się również, że św. Jacek został posłany do Krakowa przez drugiego generała Zakonu, bł. Jordana z Saksonii, a nie przez św. Dominika, co obala tradycję opartą na XIV-wiecznym Żywocie $s ́ w$. Jacka autorstwa lektora Stanisława. Można jednak przypuszczać, że św. Jacek został przyjęty do Zakonu za czasów św. Dominika, a nawet - jak podają lektor Stanisław i Jan Długosz - z rąk założyciela przyjął habit zakonny. $\mathrm{CF}^{\mathrm{WR}}$ zawiera również informacje na temat pierwszej kapituły prowincjalnej polskich dominikanów i pierwszego polskiego prowincjała, brata Gerarda z Wrocławia. Nieco inaczej musimy również spojrzeć na listę i precedencję najstarszych dominikańskich klasztorów w tej gałęzi Zakonu Kaznodziejów. Ponadto zapiska $\mathrm{CF}^{\mathrm{WR}}$ potwierdza wiarygodność relacji Jana Długosza zapisanej w LB, a tym samym wiarygodność sporządzonej przez niego listy prowincjałów.

\section{Zakończenie}

Odnaleziony w Petersburgu fragment ex cronicis fratrum otwiera nowy etap w ponad siedemdziesięcioletnich badaniach nad ,zaginioną kroniką dominikańską”. W świetle przeprowadzonych analiz możemy stwierdzić, że „zaginiona kronika dominikańska” (źródło $\Omega$ ) rzeczywiście istniała, jednak zapewne nie w takim kształcie i nie z taką zawartością, jak domniemywał G. Labuda. Możemy przyjąć tezę, że opisywała ona przede wszystkim okoliczności powstania i organizacji sieci klasztornej Prowincji Polskiej Zakonu Kaznodziejskiego. Źródło to powstało w pierwszej połowie XIII w., a jego autora należy poszukiwać wśród zakonników z pierwszego pokolenia miejscowych dominikanów. Być może był nim współczesny św. Jackowi brat Marcin z Sandomierza.

\section{A fragment of the 'lost Dominican chronicle' in the collection of the National Library of Russia, Saint Petersburg}

Summary: In the collection of the National Library of Russia in Saint Petersburg, there is a medieval manuscript under the reference number Lat. I F 212. It was produced between 1436 and 1519 among the Dominicans of the Wrocław monastery of St Adalbert (Wojciech). It is a collection of various texts by many authors: letters of the friars from Wrocław, accounts of the monastery, vestry and library inventories, a list of papal documents, copies of older records from the thirteenth to fifteenth centuries. On folio $56 \mathrm{v}$, an anonymous author presented around 1480 a 'historical collection' containing the most important and oldest documents related to the beginnings of the Wrocław monastery. Among those texts, there was also a fragment that was supposed to come from ex cronicis fratrum. A thorough analysis made it possible to establish that the text was probably written in the first half of the thirteenth century. Its author could have been a Polish Dominican, Marcin of Sandomierz, a contemporary of St Hyacinth of Poland. The text is probably a fragment of lost work, called 'the lost Dominican chronicle' by earlier historiography. It is worth emphasising that this lost source was known, among others, to Jan Długosz, who used it in his work on Liber beneficiorum, and to the fifteenth-century author of Vita antiqua beati Ceslai. Although the found text is small in size, it contains some valuable information. It finally puts an end to speculations about the time of St Hyacinth arrival in Cracow, as he was undoubtedly sent to Poland in 1222. Of course, we do not know whether St Hyacinth arrival to Cracow was the selfsame as the 'official' arrival of the Dominicans to the church Province of Gniezno, but it probably was. We also learn that St Hyacinth was sent to Cracow by the second general of the Dominican Order, Blessed Jordan of Saxony, and not by St Dominic himself. This goes against the tradition based on the fourteenth-century Life of St Hyacinth by Lector Stanislaus. The found fragment also contains information on the first Provincial Chapter of the Polish Dominicans and the first Polish provincial, Brother Gerard of Wrocław. In addition, the source confirms the credibility of Jan Długosz's account in his Liber beneficiorum and thus the reliability of his list of provincials. 
Nota o autorze: Tomasz Gałuszka OP, dr hab., ur. 1978, profesor Uniwersytetu Papieskiego Jana Pawła II w Krakowie, doktorat uzyskał na Uniwersytecie Jagiellońskim (2009), dyrektor Dominikańskiego Instytutu Historycznego w Krakowie. Specjalizuje się w historii dominikanów.

Author: Tomasz Gałuszka, OP, b. 1978, PhD in history (Jagiellonian University, 2009), Professor at the Faculty of Ancient and Medieval History at the Pontifical University of John Paul II in Cracow, Director of the Dominican Historical Institute in Cracow. He specializes in the history of the Order of Preachers.

Dominikański Instytut Historyczny

ul. Stolarska 12, 31-043 Kraków

Uniwersytet Papieski Jana Pawła II w Krakowie

Katedra Historii Starożytnej i Średniowiecznej

ul. Kanonicza 9, 31-002 Kraków

e-mail: galuszkaop@gmail.com

\section{Bibliografia}

Buko A., Poczatki Sandomierza, Warszawa 1998

Gałuszka T, „In finibus Poloniae”. Patroni i bohaterowie Polski w czternastowiecznym „Żywocie św. Jacka” autorstwa lektora Stanistawa OP, w: Dominikanie o Polsce i Polakach od XIII do XX wieku, red. T. Gałuszka, K. Matyja, Studia i Źródła Dominikańskiego Instytutu Historycznego w Krakowie, t. 21, Kraków 2020, s. 19-41

Gałuszka T., Zdanek M., „,Krakowskie” bulle rekomendacyjne Grzegorza IX a początki dominikanów polskich, St. Źródł., 44, 2006, s. 49-65

Grandjean Gøgsig Jakobsen J., Św. Jacek i Dacja. Zwiazki Apostoła Pótnocy ze Skandynawiq: prawdopodobieństwo, tradycja i aktualny stan wiedzy, w: Św. Jacek Odroważ. Apostot Pótnocnej Europy. Międzynarodowe sympozjum, Papieski Uniwersytet św. Tomasza z Akwinu „Angelicum”, Aula Jana Pawła II, Rzym, 16 października 2007 r., red. A. Nocoń, A. Wuwer, Roma-Katowice 2012, s. 97-109

Grandjean Gøgsig Jakobsen J., ,, Venerunt fratres praedicatores”. Notes on Datings of the First Dominican Convent Foundations in Scandinavia, „Collegium Medievale”, 24, 2011, s. 5-22

Kaczmarek K., Szkoły i studia polskich dominikanów w okresie średniowiecza, Poznań 2005

Kowalski M.D., Źródta i wiarygodność informacji w „Liber beneficiorum dioecesis cracoviensis” Jana Dlugosza, w: Jan Dlugosz (1415-1480). Życie i dzieła, red. L. Korczak, M.D. Kowalski, P. Węcowski, Kraków 2016, s. 103-125

Kucharski W., ,,Beatus Ceslaus natione Polonus”. Dzieje kultu błogosławionego Czesława, Studia i Źródła Dominikańskiego Instytutu Historycznego w Krakowie, t. 10, Kraków 2012

Kulpa M., Wokót czternastowiecznego „Żywota św. Jacka” - kilka zagadnień źródłoznawczych, „Nasza Przeszłość", 132, 2019, s. 5-51

Wileniec Sønderby B.A., Św. Jacek w Skandynawii: misja czy fikcja?, w: Św. Jacek Odroważ. Apostoł Pótnocnej Europy. Międzynarodowe sympozjum, Papieski Uniwersytet św. Tomasza z Akwinu „Angelicum”, Aula Jana Pawła II, Rzym, 16 października 2007 r., red. A. Nocoń, A. Wuwer, Roma-Katowice 2012, s. 110-123

Zdanek M., Figury biblijne w literackim wizerunku świętego Jacka w świetle jego najstarszej hagiografii, „Przegląd Tomistyczny", 14, 2008, s. 29-61

Zdanek M., Figury i watki biblijne w „Przedmowie” do „Żywota Świętego Jacka”, w: Święty Jacek i dziedzictwo dominikańskie, red. E. Mateja, A. Pobóg-Lenartowicz, M. Rowińska-Szczepaniak, Opole 2008, s. 163-175

Zdanek M., Stanistaw (zm. po 1371 a przed 1385-1392), w: PSB, t. 42, Kraków 2003, s. 7-9

Zdanek M., Szkoły i studia dominikanów krakowskich w średniowieczu, Warszawa 2005

Zdanek M., „Zaginiona kronika dominikańska” z XIII wieku. Próba nowego spojrzenia, w: Fontes et historia. Prace ofiarowane Antoniemu Gąsiorowskiemu, Poznań 2007, s. 245-282 